\title{
EFFECT OF THE PERCEIVED SOCIAL SUPPORT ON SCHOOL SUCCESS OF CHILDREN WITH CHRONIC DISEASE
}

\author{
Kronik Hastalığı Olan Çocukların Algıladıkları Sosyal Desteğin Okul Başarısına Etkisi \\ Gülsüm YETIŞS ${ }^{10} \quad$ Rukuye AYLAZ ${ }^{2}$ (i) \\ ${ }^{1}$ İnönü Üniversitesi, Sağllk Hizmetleri Meslek Yüksekokulu, Malatya \\ 2̇ंnönü Üniversitesi, Hemşirelik Fakültesi, Malatya
}

Geliş Tarihi / Received: 22.05.2021～Kabul Tarihi / Accepted: 21.09.2021

\begin{abstract}
This study was carried out to assess the effect of the perceived social support by chronic diseased students on their school success. This cross-sectional and descriptive research was conducted with hospitalised chronic diseased children aged between 10-16 years. Data of the study was collected by using Perceived Social Support Scale. The research has been conducted with a questionnaire method. School life of children with diagnosed chronic disease is interrupted by; frequent hospitalizations, controls, treatment approaches and medicational side effects. The children who participated the survey were determined to fall behind in their lessons and had decreased school success when compared to peers. While these factors affect children's school adaptation and success, social support has been shown have positive effects on these topics. While chronic diseases were detected to have negative effects on children's school success, perceived social support has been determined to have positive effects. Besides, children stated that existence of a school nurse would not only help in their treatment and make them feel safer at school but also would prevent absenteeism. Social support and existence of a school nurse are important factors in the school success of chronic diseased children.
\end{abstract}

Keywords: Child, Chronic disease, School achievement, School nursing, Social support.

\section{$\ddot{O Z Z}$}

$\mathrm{Bu}$ araştırma kronik hastalığı olan öğrencilerin algıladıkları sosyal desteğin okul başarılarına etkisini değerlendirmek amacıyla yapıldı. Bu kesitsel ve tanımlayıcı araştırma, 10-16 yaşları arasında hastanede yatan kronik hastalıklı çocuklarla yapılmıştır. Araştırmanın verileri Algılanan Sosyal Destek Ölçeği kullanılarak toplanmıştır. Araştırma anket uygulama yöntemiyle gerçekleştirildi. Kronik hastalığı olan çocukların okul yaşamları; sık hastaneye yatışlar, kontroller, tedavi yaklaşımları ve ilaç yan etkileri nedeniyle kesintiye uğramaktadır. Ankete katılan çocukların akranlarına göre derslerinde geri kaldıkları ve okul başarılarının azaldığı belirlendi. Bu faktörler çocukların okula uyumunu ve başarısını etkilerken, sosyal desteğin bu konularda olumlu etkileri olduğu gösterilmiştir. Kronik hastalıkların çocukların okul başarısı üzerinde olumsuz etkileri olduğu tespit edilirken, algılanan sosyal desteğin olumlu etkileri olduğu saptanmıştır. Ayrıca çocuklar, bir okul hemşiresinin varlığının sadece tedavilerine yardımcı olacağını ve kendilerini okulda daha güvende hissettireceğini değil, aynı zamanda devamsızlığı da önleyeceğini belirtmişlerdir. Sosyal destek ve bir okul hemşiresinin varlığı, kronik hastalığı olan çocukların okul başarısında önemli faktörlerdir.

Anahtar kelimeler: Çocuk, Kronik hastalık, Okul başarısı, Okul hemşireliği, Sosyal destek. 


\section{INTRODUCTION}

Over the past twenty years, the number of children with chronic diseases has been increasing significantly and chronic diseases have become one of the most important health problems worldwide (Çavuşoğlu, 2011; McClanahan \& Weismuller, 2015). There exist chronic health problems in $1-2 \%$ of the children population. Among them $10 \%$ are severe diseases which affect daily activities or require frequent treatment (Törüner \& Büyükgönenç, 2012). The incidence of chronic disease in children under the age of 18 in the world is known to be between 10-15\% (Çavuşoğlu, 2011).

In the Ordinance of 'Special Education Services of Turkey Ministry of Education', childhood chronic disease is defined as; the condition negatively affecting the individual's educational performance and social cohesion in the development period by requiring continuous nursing and treatment (MONE, 2014). School life of children with diagnosed chronic disease is interrupted by; frequent hospitalization, controls, treatment approaches and medicational side effects. These factors affect children's adaptation to school (Coyne, 2006; Crosby et al., 2015; Çavuşoğlu, 2011; Hoffmann et al., 2018; Leroy, Wallin, \& Lee, 2017; Murray, Dobbels, Lonsdale, \& Harden, 2014). In addition, the presence of health problems and their effects on organism may impact cognitive functions in learning of children and their school performance as well (Bava, Johns, Freyer, \& Ruccione, 2017; Chesney, 2014; Çavuşoğlu, 2011; Törüner \& Büyükgönenç, 2012; Yılmaz, 2008). School nurses help students in; learning chronic illness management, decreasing school absenteeism and increasing the overall academic success (NASN, 2016; Leroy et al., 2017). Children with chronic diseases are expected to continue the education process in schools while coping with the disease. This is an important issue that need support (Özcebe, 2012). For school aged children, social support from their social environment -family, teachers and friends- contribute their development and make it easier to deal with the faced problems (Boman, 2018; Brief, 2016; Fletcher-Johnston, Marshall, \& Straatman, 2011). School nurses demonstrate their roles as coordinators of care who interact and communicate with; families of children with special health care needs, school staff, health care providers and community agencies (Heuer \& Williams, 2016; McClanahan \& Weismuller, 2015).

In the researches made with students, social support has been shown to be effective in many areas, particularly in school success and school adaptation (Bordes-Edgar, Arredondo, Kurpius, \& Rund, 2011; de la Iglesia, Freiberg Hoffmann, \& Fernandez Liporace, 2014; Demirtaş, 2007; Tayfur \& Ulupinar, 2016). The aims of management of chronic diseased 
children are; to keep the children active in social life as possible as their friends, to eliminate the difficulties experienced by the disease and to maintain a healthy school life by contributing to academic success (Layte \& McCrory, 2013; Varni et al., 2015; Y1lmaz, 2008).

The chronic diseased child's support from social environment effects school attendance and also the school success. Nurses have important roles in; obtaining health-related obstacles, children's coping with health problems, helping for a healthy life in school age and adulthood (Harper, Liddon, Dunville, \& Habel, 2016; Houlahan, 2018).

School life and academic achievement of children with diagnosed chronic disease are frequently interrupted by disease-induced factors as hospitalizations, controls, treatment approaches and medicational side effects. While these factors affect children's school adaptation and success, social support has been shown to have positive effects on these topics. The purpose of the study is to investigate the effect of perceived social support on school success of the chronic diseased children. For this aim we have questioned whether perceived social support of the children with chronic disease effect school success or not.

\section{MATERIAL AND METHOD}

This cross-sectional and descriptive study was conducted on children with chronic diseases aged between 10-16 years, among August 2012 and December 2013. The universe of the research included 597 children hospitalised in a Hospital Children Service. Among the universe, 234 children were selected by simple random sampling method (calculated by the sampling formula for known universe) (Aktürk \& Acemoğlu, 2011). As the age limit for the application of Perceived Social Support Scale' (PSSS) was 10, children under 10 years of age were excluded from the study (Yıldırım, 2004). The research has been conducted with a questionnaire method.

\section{Data Collection Tools}

The forms prepared by the researcher, including; Chronic Diseased Children Information Form and Perceived Social Support Scale (PSSS) were distributed and filled by children who agreed to participate after being given information about the purpose of the study. PSSS has been developed in 1995 by Yildırım in order to determine the level of individual's social support from the society including family, relatives, friends, teachers, institutions. It has been revised in 2004 (Y1ldırım, 2004). The scale composed of three sub-scales; my family, my friends and my teachers, and consists of 50 questions in total. Answers are provided in the form of triple grading $($ never $=$ Not applicable 1 , Partially suitable $=2$, Highly available $=3$ ) and among them 
47 statements are positive while 3 are negative. The score of each subscale is obtained by the collection of positive and negative statements' scores. The height of the score reflects the level of the social support the individual get. The sum of sub-scale scores are recorded as General Social Support Score (Yıldırım, 2004). Alpha reliability coefficient conducted by Yildırım, after the reliability and validity study has been found to be 0.93 for the whole scale and 0.79 for family (AI), 0.74 for friend (AR), 0.75 for teacher (ÖĞ), and 0.80 for society (T) subscales (Yildirim, 2006). In this research, Cronbach alpha reliability coefficient has been found to be 0.88 for the entire scale, 0.82 for Family subscale, 0.82 for Friend sub-scale, 0.79 for Teacher sub-scale.

\section{Statistical Analysis of Data}

In the statistical analysis of the data; descriptive statistics (number, percent, mean, standard deviation), variance analysis, chi-square, Kruskal-Wallis, Mann-Whitney U and t tests were used. Results were evaluated at $95 \%$ confidence interval and significance level as $\mathrm{p}<0.05$.

\section{Ethical Aspects of the Research}

In order to perform the research, written permission was taken from the hospital where the study was conducted, and the research protocol was approved by the ethical committee of the institute where the research was performed (date: 31.07.2012, decision number 2012/136). Additionally; written permission was taken from Y1ldırım (who has developed the PSSS and made the reliability and validity studies) and oral consent from the children and their parents were taken.

\section{RESULTS}

The research was planned to be performed with 234 chronic diseased children who were older than 10 years and were selected by simple random sampling method, all the participants joined to the study.

Table 1: Comparison of Chronic Diseased Children Patients Socio-Demographic Characteristics with PSS Scale Scores $(n=234)$

\begin{tabular}{|c|c|c|c|c|c|}
\hline \multirow[b]{2}{*}{ Features } & \multirow[b]{2}{*}{$\mathbf{S}(\%)$} & \multicolumn{2}{|c|}{ PSS Family Scale Score Mean } & \multicolumn{2}{|c|}{ PSS Friend Scale Score Mean } \\
\hline & & $\overline{\mathbf{X}} \pm \mathbf{S S}$ & Significance & $\overline{\mathbf{X}} \pm \mathbf{S S}$ & Significance \\
\hline \multicolumn{6}{|l|}{ Age } \\
\hline 10-14 age & $182(77.8)$ & $54.6 \pm 4.49$ & \multirow{2}{*}{$\begin{array}{l}\mathrm{t}=1.982 \\
\mathbf{p}=\mathbf{0 . 0 4 9}^{\mathrm{a}}\end{array}$} & $34.12 \pm 4.50$ & \multirow{2}{*}{$\begin{array}{l}\mathrm{t}=-0.199 \\
\mathrm{p}=0.843^{\mathrm{a}}\end{array}$} \\
\hline $15-16$ age & $52(22.2)$ & $53.1 \pm 5.58$ & & $34.26 \pm 4.78$ & \\
\hline \multicolumn{6}{|l|}{ Gender } \\
\hline Female & $109(46.6)$ & $54.1 \pm 4.56$ & \multirow{2}{*}{$\begin{array}{l}\mathrm{t}=-0.504 \\
\mathrm{p}=0.615^{\mathrm{a}}\end{array}$} & $34.44 \pm 4.37$ & \multirow{2}{*}{$\begin{array}{l}\mathrm{t}=0.884 \\
\mathrm{p}=0.378^{\mathrm{a}}\end{array}$} \\
\hline Male & $125(53.4)$ & $54.4 \pm 4.97$ & & $33.91 \pm 4.71$ & \\
\hline
\end{tabular}




\begin{tabular}{|c|c|c|c|c|c|}
\hline Only child of the family & $11(4.7)$ & $56.27 \pm 2.96$ & $\mathrm{KW}=3.153$ & $35.63 \pm 2.20$ & \multirow{2}{*}{$\begin{array}{l}\mathrm{KW}=3.903 \\
\mathrm{p}=0.142^{\mathrm{c}}\end{array}$} \\
\hline $2-5$ siblings & $200(85.5)$ & $54.34 \pm 4.82$ & $\mathrm{p}=0.207^{\mathrm{c}}$ & $33.97 \pm 4.60$ & \\
\hline 6 and/or more & $23(9.8)$ & $53.26 \pm 4.96$ & & $35.08 \pm 4.83$ & \\
\hline & \multicolumn{3}{|c|}{ PSS Teacher Scale Score Mean } & \multicolumn{2}{|c|}{ PSS Scale Total Score Mean } \\
\hline Features & S(\%) & $\overline{\mathbf{X}} \pm \mathbf{S S}$ & Significance & $\overline{\mathbf{X}} \pm \mathbf{S S}$ & Significance \\
\hline \multicolumn{6}{|l|}{ Age } \\
\hline 10-14 age & $182(77.8)$ & $45.80 \pm 5.92$ & $\mathrm{t}=2.458$ & $134.58 \pm 11.89$ & $\mathrm{t}=1.969$ \\
\hline $15-16$ age & $52(22.2)$ & $43.42 \pm 6.97$ & $\mathrm{p}=0.015^{\mathrm{a}}$ & $130.86 \pm 12.45$ & $\mathrm{p}=0.050^{\mathrm{a}}$ \\
\hline \multicolumn{6}{|l|}{ Gender } \\
\hline Female & $109(46.6)$ & $45.95 \pm 5.54$ & $\mathrm{t}=1.554$ & $134.55 \pm 10.83$ & $\mathrm{t}=0.932$ \\
\hline Male & $125(53.4)$ & $44.68 \pm 6.74$ & $\mathrm{p}=0.122^{\mathrm{a}}$ & $133.07 \pm 13.10$ & $\mathrm{p}=0.352^{\mathrm{a}}$ \\
\hline \multicolumn{6}{|l|}{ Number of siblings } \\
\hline Only child of the family & $11(4.7)$ & $45.27 \pm 8.34$ & $\mathrm{KW}=0.308$ & $137.18 \pm 10.05$ & $\mathrm{KW}=0.725$ \\
\hline $2-5$ siblings & $200(85.5)$ & $45.45 \pm 5.83$ & $\mathrm{p}=0.857^{\mathrm{c}}$ & $133.76 \pm 11.93$ & $\mathrm{p}=0.696^{\mathrm{c}}$ \\
\hline 6 and/or more & $23(9.8)$ & $43.78 \pm 8.33$ & & $132.13 \pm 14.41$ & \\
\hline
\end{tabular}

$53.4 \%$ of the participants were male, average age was determined to be $12.76 \pm 1.95$. According to the obtained data; the score between PSS families sub-scale, PSS teacher subscale and total scale have been found to be statistically significant among the 10-14 age group and 15-16 age group. This result points out 10-14 age group to take more support from family, teacher and in total (Table 1). Mean score obtained between age and PSS friends scale was not significant ( $p>0.05)$. Mean score difference between sex, number of siblings, PSS sub-scales and PSS total scale was determined to be statistically insignificant ( $p>0.05)$.

Table 2: Comparison of Demographic Characteristics of Parents of Children with PSS Scores Received From Family Scale $(\mathrm{n}=234)$

\begin{tabular}{llllll}
\hline \multirow{2}{*}{ Features } & \multicolumn{3}{c}{ PSS Family Scale Score Mean } & \multirow{2}{*}{ Significance } \\
\cline { 2 - 5 } & $\mathbf{S}$ & $\%$ & $\overline{\mathbf{X}} \pm$ & $\mathrm{SS}$ & \\
\hline Mother's job & & & & & \\
\hline Housewife & 221 & $(94.4)$ & 54.21 & 4.81 & $\mathrm{U}=1062.5$ \\
\hline Working & 13 & $(5.6)$ & 56.23 & 3.72 & $\mathrm{p}^{2} 0.113^{\mathrm{b}}$ \\
\hline Father's job & & & & \\
\hline Self-employment & 153 & $(65.4)$ & 54.09 & 4.80 & $\mathrm{f}=1.815$ \\
\hline Workman & 41 & $(17.5)$ & 53.92 & 4.55 & $\mathrm{p}=0.165^{\mathrm{c}}$ \\
\hline Officer & 40 & $(17.1)$ & 55.62 & 4.82 & \\
\hline Economic Status & & & & & \\
\hline Good & 89 & $(38.0)$ & 54.80 & 4.72 & $\mathrm{KW}=3.696$ \\
\hline Moderate & 120 & $(51.3)$ & 54.15 & 4.86 & $\mathrm{p}=0.158^{\mathrm{a}}$ \\
\hline Bad & 25 & $(10.7)$ & 54.32 & 4.78 & \\
\hline
\end{tabular}

${ }^{\mathrm{a}}$ Kruskal-Wallis, ${ }^{\mathrm{b}}$ Mann-Whitney U test, ${ }^{\mathrm{c}}$ ANOVA $(\mathrm{p}<0.05)$

The difference in the average scores between the children's parents education, job and economic status with PSS family scale was not statistically significant ( $p>0.05)$ (Table 2). 
Table 3: Comparison of Children's School Success Before and After the Disease ( $\mathrm{n}=234)$

\begin{tabular}{|c|c|c|c|c|c|c|c|}
\hline \multirow{3}{*}{ School Success } & \multicolumn{4}{|c|}{ After Disease } & & & \multirow{3}{*}{ Significance } \\
\hline & \multicolumn{2}{|c|}{ Successful } & \multicolumn{2}{|c|}{ Unsuccessful } & \multicolumn{2}{|c|}{ Total } & \\
\hline & $\mathbf{S}$ & $\%$ & $\mathbf{S}$ & $\%$ & $\mathbf{S}$ & $\%$ & \\
\hline \multicolumn{8}{|l|}{ Before Disease } \\
\hline Successful & 140 & 71.8 & 55 & 28.2 & 195 & 83.3 & $p=0.001$ \\
\hline Unsuccessful & 3 & 7.7 & 36 & 92.3 & 39 & 16.7 & \\
\hline Total & 143 & 61.1 & 91 & 38.9 & 234 & 100 & \\
\hline
\end{tabular}

Fisher's Exact test

The relationship between school success and presence of chronic disease was found to be statistically significant according to the children's statements. It was found that the disease effected the success in a negative way (Table 3 ).

Table 4: Benefits of Presence of Nurse at School According to Chronic Diseased Children

\begin{tabular}{lll}
\hline Benefits of Presence of Nurse at school & S & \% \\
\hline Helps us to continue the disease treatment. & 132 & 56.4 \\
\hline I won't worry about my illness at school. & 131 & 56.0 \\
\hline I would feel safe at school, I would not do absenteeism. & 122 & 52.1 \\
\hline Does not mean anything, it does not matter to me. & 39 & 16.7 \\
\hline
\end{tabular}

More than half of the chronic diseased children stated that school nurse would help in their treatment and they would not worry about their illness at school. They would also feel safer at school and would not do absenteeism with a school nurse (Table 4).

Table 5: Comparison of Chronic Diseased Children's School Success with PSSS scores $(n=234)$

\begin{tabular}{|c|c|c|c|c|c|c|c|c|}
\hline \multirow[t]{2}{*}{$\begin{array}{l}\text { School } \\
\text { Status }\end{array}$} & \multicolumn{2}{|c|}{$\begin{array}{l}\text { Family Sub-scale } \\
\text { Average Score }\end{array}$} & \multicolumn{2}{|c|}{$\begin{array}{l}\text { Friend Sub- } \\
\text { scale } \\
\text { Average Score }\end{array}$} & \multicolumn{2}{|c|}{$\begin{array}{l}\text { Teacher Sub-scale } \\
\text { Average Score }\end{array}$} & \multicolumn{2}{|c|}{$\begin{array}{l}\text { PSSS Total } \\
\text { Average Score }\end{array}$} \\
\hline & $\overline{\mathbf{X}} \pm$ & SS & $\overline{\mathbf{X}} \pm$ & SS & $\overline{\mathbf{X}} \pm$ & SS & $\overline{\mathbf{X}} \pm$ & SS \\
\hline Successful & 54.9 & 4.40 & 35.0 & 4.24 & 46.3 & 5.18 & 136.36 & 11.24 \\
\hline Unsuccessful & 53.3 & 5.19 & 32.8 & 4.74 & 43.5 & 7.29 & 129.67 & 12.31 \\
\hline $\mathbf{t}$ & 2.570 & & 3.665 & & 3.530 & & 4.276 & \\
\hline $\mathbf{p}$ & 0.011 & & 0.001 & & 0.001 & & 0.001 & \\
\hline
\end{tabular}

Independent groups $\mathrm{t}$ test

The difference between school success of children with PSS sub-scales, PSSS and received average scores were found to be statistically significantly different $(p<0.05)$ (Table 5). The school success was obtained to improve with the increase of perceived social support from family, friends and teachers. When the school success of children was compared with PSSS score; family received support was found to be the highest affecting factor (54.9 \pm 4.40$)$, followed by the support of teachers $(46.3 \pm 5.18)$ and the support of friends $(35.0 \pm 4.24)$ respectively. 


\section{DISCUSSION}

Puberty has independent, negative influences on school outcomes. Healthy adolescent period reduces the potential adverse effects of academic achievement, school and pubertal processes in children (Forrest, Bevans, Riley, Crespo, \& Louis, 2013). Chronic disease in school age may affect school adaptation and school success by causing social problems (Bonaiuto, 2007; Engelke, Guttu, Warren, \& Swanson, 2008; Forrest et al., 2013; Gracey \& Ward, 2012; McClanahan \& Weismuller, 2015; Y1lmaz, 2008). In this study, it has been determined that chronic disease is negatively affecting the students' success. There exists statistically significant difference in school success before and after the disease onset (Table 3). Engelke and et al's (2008) and Y1lmaz's (2008) researches -with elementary and high school chronic diseased students- concluding with the adverse correlation in school success and frequent hospitalisation shows similarities with the findings of this research.

When the children were asked about benefits of the presence of health nurses in school and their support; the majority of children stated that they would worry less and feel safer in school as the nurse would help in their treatment (Table 4). In Bonaiuto's (2007) study, school success of chronically diseased children have been shown to have increased in the schools that have full-time school nurse. Engelke et al. (2008) have concluded that school health nurse services have improved school success of chronically diseased children. Krenitsky Korn's (2011) and Engelke et al's (2014) researches about 'students with asthma' have reached the conclusion that presence of school health nurse decreases absenteeism and increases children's success in school (Engelke, Swanson \& Guttu, 2014). These studies support the findings of this research.

Family, friends and teachers are the social support factors of school aged children (Gracey \& Ward, 2012; Y1ldırım, 2004). In this study; while the age of the children and PSSS; family, teacher sub-scales and total scale scores have been found to be statistically significant, friend sub-scale was not statistically significant. 10-14 age group have been found to be taking more support from their families and teachers when compared to the 15-16 age group. Friend support did not vary with the age, it was found that they got support from friends in both age groups (Table 1). Jackson et al's study which points out that the difference in the perceived social support with age is important and perceived social support decline with increasing age is in favor of this research (Jackson, Tucker, \& Herman, 2007). The decline in perceived social support from family may be because of the child's peer assessment perception of that age 
(Törüner \& Büyükgönenç, 2012). Barrera et al (2008)'s and Bokhorst et al (2010)'s studies concluded that there was no significant difference among other social support factors but there exists a decline in teacher support by increasing age (Barrera, Andrews, Burnes \& Atenafu, 2008; Bokhorst, Sumter \& Westenberg, 2010). These results help us to explain our finding of teacher support difference with age.

In this study, the child's number of siblings has not been found to be effective on social support taken from the family (Table 1). Şencan (2009)'s and Ateş (2012)'s researches indicating decreased social support of the families with increase in number of siblings show difference with results of this study. This difference makes us to think that families give priority for chronic diseased child's social support.

Perceived social support scores in this study were not statistically significant among educational status of parents, economic status and the mothers working situation (Table 2). Demirtaş (2007)'s and Şencan (2009)'s researches concluding that increase in parents' educational levels and economic levels result in increase in perceived social support differs with the findings of this research. Ateş's (2012) study which points out that the mothers employment status effect the relationship between the perceived social support from family in a negative manner does not show similarity with this research. These differences may be explained by the parents' attention span for social support to diseased children, and it is not related with the education level or the economic status of the family. It also suggests that working mothers may be giving priority to chronic diseased child.

In this study difference between school success and PSSS family, friend, teacher subscale scores and total score have been found to be statistically significant. School success increases with the more social support level that chronic diseased children get from their families, teachers and friends. Children's school success is mostly affected by the support taken from family, friends and teachers, respectively (Table 5). Many studies have detected that family is one of the most important factors of social support in academic performance. In Demirtaş (2007), Somers et al. (2008), Ateş (2012), Gracey (2012)'s studies with primary and secondary school students, an important relationship between social support -from families, friends and teachers- and school achievement scores have been determined (Gracey \& Ward, 2012; Somers, Owens \& Piliawsky, 2008). In mentioned studies academic achievement increases by perceived social support and this promotes the findings of this research.

The fact that, this research gives only the results of one hospital can be taken as the limitation of the study, wider studies including more hospitals and cities would provide more 
effective evaluation about the effect of the perceived social support on school success of children with chronic disease.

\section{CONCLUSION}

As the result of the research, the following findings were obtained;

- The difference between chronic disease existence (before and after the disease onset) and school success of children have been found to be statistically significant, the chronic disease has been determined to have negative affects on school success.

- The perceived social support have positive effects on children's school success; the most important factor for success is the support received from family, and then teacher and friend support respectively.

- It is determined that the presence of school nurse help children feel safer.

In accordance with the results obtained from this study the following recommendations can be made;

Determination of the children's level of social support and support resources, implementation of nursing interventions are required in the ensurement of the lack of support,

$\checkmark$ Informing the family, teacher, friend and social environment on the impact of the child's disease and its affects, and giving consultancy services when necessary,

$\checkmark$ Organisation and implementation of school health services in all schools in our country and activation of school health nursing,

$\checkmark$ More extensive studies about the school life and the problems chronic diseased children experience may be advised to be made.

Children with chronic diseases face a lot of problems in their academic achievement. This research points out the importance of social support and existence of a school nurse in the school success of chronic diseased children.

This study was presented as a poster at the "1st International 2nd National Public Health Nursing Congress, 2018".

\section{REFERENCES}

Aktürk, Z., \& Acemoğlu, H. (2011). Săglık Çalışanları İçin Araştırma ve Pratik İstatistik. İstanbul: Anadolu printing house.

Ateş, B. (2012). Ortaöğretim öğrencilerinin sosyal destek algllarının bazı değişkenlere göre incelenmesi. Akademik Bakış Dergisi, 30(3), 1-16. 
Barrera, M., Andrews, G. S., Burnes, D., \& Atenafu, E. (2008). Age differences in perceived social support by paediatric haematopoietic progenitor cell transplant patients: a longitudinal study. Child Care Health Dev, 34(1), 19-24.

Bava, L., Johns, A., Freyer, D. R., \& Ruccione, K. (2017). Development of a culturally competent service to improve academic functioning for Latino survivors of acute lymphoblastic leukemia: methodological considerations. Journal of Pediatric Oncology Nursing, 34(3), 222-229.

Bokhorst, C. L., Sumter, S. R., \& Westenberg, P. M. (2010). Social Support from Parents, Friends, Classmates, and Teachers in Children and Adolescents Aged 9 to 18 Years: Who Is Perceived as Most Supportive? Social Development, 19(2), 417-426.

Boman, A. (2018). Learning by supporting others-experienced parents' development process when supporting other parents with a child with type 1 diabetes. Journal of clinical nursing, 27(5-6), e1171-e1178.

Bonaiuto, M. M. (2007). School nurse case management: achieving health and educational outcomes. Journal of School Nursing, 23(4), 202-209.

Bordes-Edgar, V., Arredondo, P., Kurpius, S. R., \& Rund, J. (2011). A longitudinal analysis of Latina/o students' academic persistence. Journal of Hispanic Higher Education, 10(4), 358-368.

Brlef, S. H. I. (2016). Available from http://www.cdfny.org/research-library/publications/2016/school-healthbriefs-2016.pdf. Accessed 6 February 2017.

Chesney, M. L. (2014). Education-An Important Prescription for Health. Journal of Pediatric Health Care, 28(5), 374-375.

Coyne, I. (2006). Children's experiences of hospitalization. Journal of child health care, 10(4), 326-336.

Crosby, L. E., Joffe, N. E., Irwin, M. K., Strong, H., Peugh, J., Shook, L., . . Mitchell, M. J. (2015). School Performance and Disease Interference in Adolescents with Sickle Cell Disease. Phys Disabil, 34(1), 14-30.

Çavuşoğlu, H. (2011). Çocuk Sağlı̆̆ı Hemşireliği (Vol. Cilt I.). Ankara Sistem Ofset printing house.

De la Iglesia, G., Freiberg Hoffmann, A., \& Fernandez Liporace, M. (2014). Perceived parenting and social support: can they predict academic achievement in Argentinean college students? Psychol Res Behav Manag, 7, 251-259.

Demirtaş, A. S. (2007). The relationship between perceived social support, loneliness and the coping stress levels of the students attending the 8 th class in elementary schools. (Master's thesis), Gazi University, Ankara.

Engelke, M. K., Guttu, M., Warren, M. B., \& Swanson, M. (2008). School Nurse Case Management for Children With Chronic Illness: Health, Academic, and Quality of Life Outcomes. Journal of School Nursing, 24(4), 205-214.

Engelke, M. K., Swanson, M., \& Guttu, M. (2014). Process and Outcomes of School Nurse Case Management for Students With Asthma. Journal of School Nursing, 30(3), 196-205.

Fletcher-Johnston, M., Marshall, S. K., \& Straatman, L. (2011). Healthcare transitions for adolescents with chronic life-threatening conditions using a Delphi method to identify research priorities for clinicians and academics in Canada. Child Care Health and Development, 37(6), 875-882.

Forrest, C. B., Bevans, K. B., Riley, A. W., Crespo, R., \& Louis, T. A. (2013). Health and School Outcomes During Children's Transition Into Adolescence. Journal of Adolescent Health, 52(2), 186-194.

Gracey, B. B., \& Ward, W. L. (2012). Assisting With School Absences for Pediatric Health Conditions: Written Information for Families. Journal of Pediatric Health Care, 26(5), 374-379. 
Harper, C. R., Liddon, N., Dunville, R., \& Habel, M. A. (2016). High School Students' Self-Reported Use of School Clinics and Nurses. Journal of School Nursing, 32(5), 324-328.

Heuer, B., \& Williams, S. (2016). Collaboration Between PNPs and School Nurses: Meeting the Complex Medical and Academic Needs of the Child With ADHD. Journal of Pediatric Health Care, 30(1), 88-93.

Hoffmann, I., Diefenbach, C., Gräf, C., König, J., Schmidt, M. F., Schnick-Vollmer, K., . . Group, i. S. (2018). Chronic health conditions and school performance in first graders: A prospective cohort study. PloS one, 13(3), e0194846.

Houlahan, B. (2018). Origins of School Nursing. The Journal of School Nursing, 34(3), 203-210.

Jackson, E. S., Tucker, C. M., \& Herman, K. C. (2007). Health value, perceived social support, and health selfefficacy as factors in a health-promoting lifestyle. Journal of American College Health, 56(1), 69-74.

Krenitsky-Korn, S. (2011). High school students with asthma: attitudes about school health, absenteeism, and its impact on academic achievement. Journal of Pediatric Nursing, 37(2), 61-68.

Layte, R., \& McCrory, C. (2013). Paediatric chronic illness and educational failure: the role of emotional and behavioural problems. Soc Psychiatry Psychiatr Epidemiol, 48(8), 1307-1316.

Leroy, Z. C., Wallin, R., \& Lee, S. (2017). The Role of School Health Services in Addressing the Needs of Students With Chronic Health Conditions. Journal of School Nursing, 33(1), 64-72.

McClanahan, R., \& Weismuller, P. C. (2015). School nurses and care coordination for children with complex needs: an integrative review. Journal of School Nursing, 31(1), 34-43.

MONE, M. O. N. E. Millı̂ Eğitim Bakanlı̆̆ Özel, Özel Eğitim Kurslarl Yönetmeliği Resmî Gazete: 22.7.2005/25883. Available from http://mevzuat.meb.gov.tr/html/66.html. Accessed 5 June 2014.

Murray, P. D., Dobbels, F., Lonsdale, D. C., \& Harden, P. N. (2014). Impact of end-stage kidney disease on academic achievement and employment in young adults: a mixed methods study. Journal of Adolescent Health, 55(4), 505-512.

NASN, N. A. o. S. N. (2016). Position Statement: Chronic health conditions managed by school nurses. 6 February 2017 retrieved from https://www.nasn.org/portals/O/binder_papers_reports.pdf.

Özcebe, H. (2012). Okul sağllğı hizmetlerinde mevcut durum ve model beklentisi. Paper presented at the Halk Sağllğı Günleri 2.Ulusal Okul Sağllğı Sempozyumu, Adana: Çukurova University.

Somers, C. L., Owens, D., \& Piliawsky, M. (2008). Individual and social factors related to urban African American adolescents' school performance. The High School Journal, 91(3), 1-11.

Sencan, B. (2009). Research of the perceived social support level by high school students and social self efficacy expectation level according to some variable. (Master's thesis), Çukurova University, Adana.

Tayfur, C., \& Ulupinar, S. (2016). The Effect of Perceived Social Support on Academic Achievement in Health College Students. Journal of Psychiatric Nursing, 7(1), 1-6.

Törüner, E. K., \& Büyükgönenç, L. (2012). Çocuk Sağlığı Temel Hemşirelik Yaklaşımları. Ankara: Gökçe ofset (Göktuğ publishing).

Varni, J. W., Bendo, C. B., Denham, J., Shulman, R. J., Self, M. M., Neigut, D. A., . . Pohl, J. F. (2015). PedsQL (TM) Gastrointestinal Symptoms Scales and Gastrointestinal Worry Scales in pediatric patients with functional and organic gastrointestinal diseases in comparison to healthy controls. Quality of Life Research, 24(2), 363-378.

Ylldırım, İ. (2004). Algılanan sosyal destek ölçeğinin revizyonu. Eğitim Araştırmaları-Eurasian Journal of Educational Research, 17, 221-236. 
Effect of the Perceived Social Support on School Success of Children with Chronic Disease Gülsüm YETIŞ, Rukuye AYLAZ

Yildirim, I. (2006). Akademik başarının yordayıcısı olarak gündelik sıkıntılar ve sosyal destek. Hacettepe Üniversitesi Eğitim Fakültesi Dergisi, 30(30).

Yllmaz, G. (2008). Family-school relationship of primary school students with chronic disease. (Master's thesis). Atatürk University, Erzurum. 